\title{
Single Beat QTcV Interval
}

National Cancer Institute

\section{Source}

National Cancer Institute. Single Beat QTCV Interval. NCI Thesaurus. Code C123451.

The correction of the QT interval within a single beat using the Van der Water's formula. 